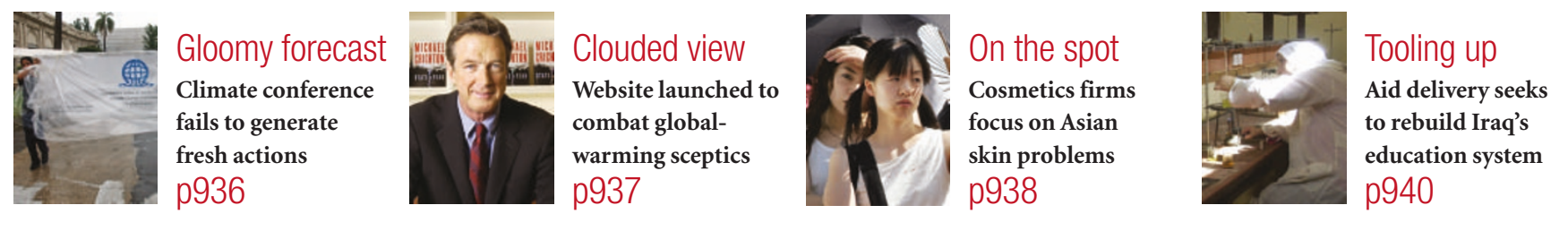

\title{
Activists and researchers rally behind AIDS drug for mothers
}

\section{Erika Check, Washington}

Scientists and patient advocates this week united to defend an HIV treatment against allegations that a key clinical trial of the drug was flawed.

The drug, nevirapine, is used to help prevent mother-to-baby transmission of HIV. But stories published by the Associated Press earlier this month re-ignited controversy in Africa over whether nevirapine is safe and effective, raising fears that many women there will stop taking the drug.

The allegations relate to a clinical trial known as HIVNET 012 and funded by the US National Institutes of Health (NIH) which began in 1997 in Uganda. In 1999 and in 2003, the scientists running the trial reported that nevirapine drastically cut mother-to-child transmission of HIV ${ }^{1,2}$. The findings led to successful transmission prevention programmes around the world.

The Associated Press stories drew on internal communications between Edmund Tramont, head of the NIH's Division of AIDS, and his subordinates, who were concerned about standards of record keeping in the trial. Tramont, however, believed that a thorough review of the study had validated the conclusions that nevirapine was safe and effective, and stated this in a final report in March 2003.

Scientists and advocates are standing by Tramont's conclusion, pointing out that independent trials in South Africa, Malawi and Thailand ${ }^{3-5}$ have confirmed it. But nevirapine has long been a flash point in the AIDS epidemic, especially in South Africa (see Nature 430, 389; 2004), and the latest stories have revived vitriolic arguments about its use.

The African National Congress, the governing party in South Africa, issued an unsigned statement on 17 December, alleging that the drug was not proven to be safe but that the United States "was happy that the peoples of Africa should be used as guinea pigs". And on 16 December, the US political leader and civil-rights activist Jesse Jackson branded the NIH's continued support for the drug "a crime against humanity".

The NIH has asked the Institute of Medicine to perform an independent study of HIVNET 012, which will report in March.

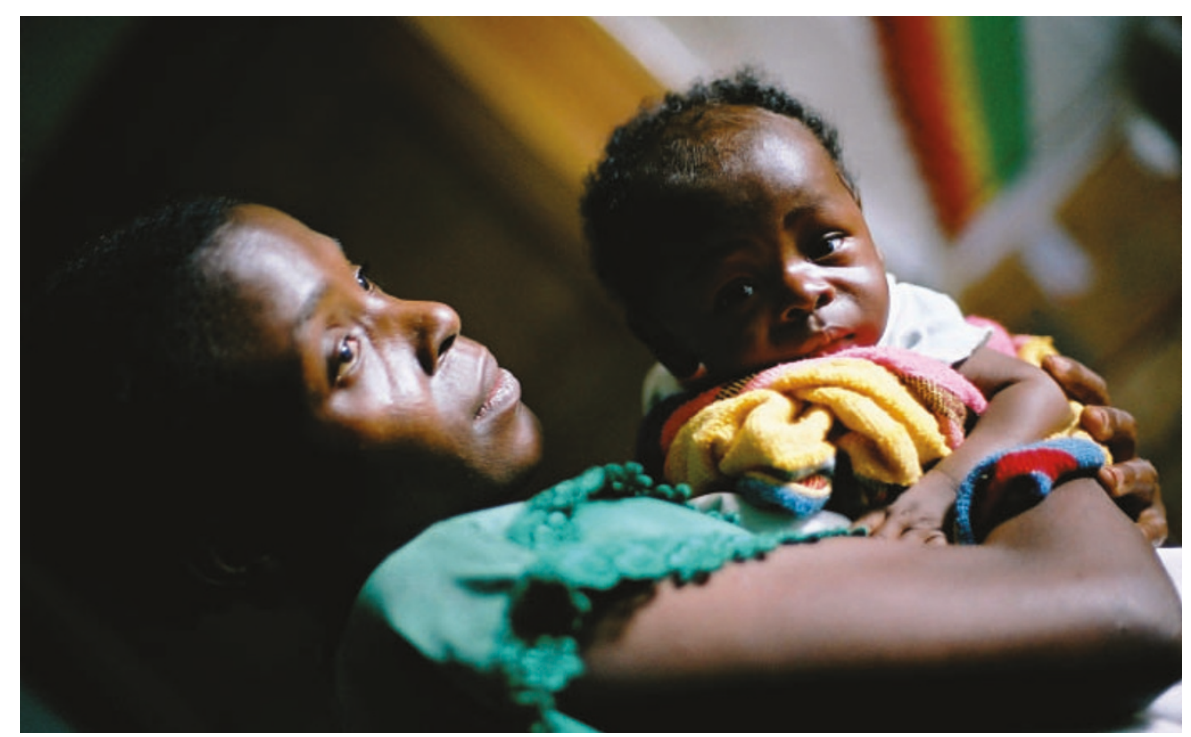

Nevirapine is widely used in Africa to prevent the transmission of HIV from mother to child.

Officials at the NIH admit that the trial was not done perfectly, but they strongly support Tramont's decision to back the drug's use over the opinions of some of his subordinates.

"There certainly were elements of the study that could have been done better," says Clifford Lane, acting deputy director of the National Institute of Allergy and Infectious Diseases (NIAID). "But there's nothing that has in any way invalidated the conclusion that single-dose nevirapine is effective for reducing mother-to-child transmission."

\section{Strong support}

Academics also defended the conclusion. "Ed Tramont is a man of integrity and common sense, and he has probably done more than anybody at the NIH to improve the infrastructure for conducting these trials in developing countries," says Brooks Jackson, a pathologist at Johns Hopkins Medicine in Baltimore, who led HIVNET 012.

Brooks Jackson adds that he stands by the trial's results: "There's no question in my mind that single-dose nevirapine is safe and efficacious, and now that's been supported by several other studies independent of ours."

Even activists who often clash with the NIAID say that top scientists there correctly interpreted evidence from the trial, despite some flaws in the study. "The data discrepancies don't alter the fundamental fundings," says Gregg Gonsalves of Gay Men's Health Crisis, an AIDS lobby group in New York.

The furore over HIVNET 012 underscores the difficulties of doing clinical trials in developing countries. "You get criticized because some people feel you should provide the same exact standard of care as you do in the United States, and it's just not feasible," says Brooks Jackson. "On the other hand, you get criticized for doing regimens that are too difficult or cost too much or are not realistic, so you're sort of caught in the middle."

But activists are worried that the latest controversy is undermining efforts to prevent HIV transmission in Africa. "There are already mothers who are refusing to take nevirapine," says Arthur Ammann, a doctor and president of Global Strategies for HIV Prevention, a non-profit organization based in San Rafael, California. "This is the most successful therapy in the entire AIDS epidemic. It should not be attacked."

1. Guay, L. A. et al. Lancet 354, 795-802 (1999).

2. Jackson, J. B. et al. Lancet 362, 859-868 (2003).

Moodley, D. et al. J. Infect. Dis. 187, 725-735 (2003).

4. Taha, T. E. et al. Lancet 362, 1171-1177 (2003).

Lallemant, M. et al. N. Engl. J. Med. 351, 217-228 (2004). 